\title{
CZEGO MOŻEMY SIĘ NAUCZYĆ OD REINHARTA KOSELLECKA, CZYLI O POTRZEBIE BADANIA POLSKIEJ SEMANTYKI HISTORYCZNEJ
}

\section{ROZMOWA Z PROFESOREM MACIEJEM JANOWSKIM}

Kornelia Kończal

Universität Erfurt

Kornelia Kończal: Dlaczego historia pojéc leży w Polsce odtogiem?

Maciej Janowski: Historia pojęć może nie tyle leży w Polsce odłogiem, ile nie przebiła się do głównego nurtu nauk społecznych i humanistycznych, a prace, które można by uznać za wpisujące się w tę perspektywę badawczą, powstały niezależnie od zachodnioeuropejskich tradycji. Najważniejszą polską książką podejmującą tę problematykę jest moim zdaniem wciąż jeszcze wydana w 1961 roku praca Franciszka Pepłowskiego Stownictwo i frazeologia polskiej publicystyki okresu Oświecenia i Romantyzmu. Niestety bez większego echa przeszły w Polsce wydawane w Niemczech Zachodnich od lat 70. Geschichtliche Grundbegriffe i - mimo dostępnych po polsku przekładów - prace teoretyczne głównego twórcy tego monumentalnego leksykonu niemieckiego języka społeczno-politycznego Reinharta Kosellecka. To samo dotyczy dorobku działającej w Wielkiej Brytanii Cambridge School [por. artykuł Jerzego Szackiego w tym numerze SR - przyp. red.].

KK: Jak wyjaśnia Pan ten brak recepcii?

MJ: Moim zdaniem kluczowe znaczenie ma to, że badanie historii pojęć jest po prostu trudne. Przyjrzyjmy się historiografii po Annales. Dwie

\footnotetext{
1 Szkoła Annales (franc. école des Annales) - środowisko francuskich historyków skupionych początkowo wokół wydawanego od 1929 roku periodyku „Annales d'histoire économique et sociale” (od
} 
najważniejsze innowacje w tym okresie to właśnie historia pojęć w rozumieniu Reinharta Kosellecka oraz stworzona przez Pierre'a Norę koncepcja miejsc pamięci (lieux de mémoire). Dlaczego ta druga zrobiła oszałamiająca karierę, a ta pierwsza karierę co najwyżej umiarkowaną? Powodów jest pewnie dużo, ale jednym z nim jest na pewno to, że badanie miejsc pamięci jest - przynajmniej na pierwszy rzut oka - zdecydowanie prostsze niż pisanie historii pojęć. Gdyby ktoś kazał nam teraz a vista napisać esej pt. „Grunwald jako polskie miejsce pamięci”, tobyśmy ten esej z pamięci, bez pójścia do biblioteki napisali. Z kolei napisanie czegokolwiek sensownego o historii pojęć, odsłanianie ich zapomnianych, ale przecież podziemnie nurtujących znaczeń wymaga wielu lat szczegółowych studiów i analizy ogromnej ilości tekstów. Dlatego też pisanie historii pojęć ma sens tylko jako zajęcie zespołowe. Tymczasem realizowanie zakrojonych na szeroka skalę projektów badawczych nie cieszy się w polskich naukach społecznych i humanistycznych popularnością.

KK: Czego nie wiemy o Polsce, nie znajac historii polskiego jezyka spoteczno-politycznego?

MJ: Dla historyka nieznajomość semantyki historycznej oznacza olbrzymie niebezpieczeństwo nierozumienia źródeł. Ogólniej rzecz ujmując, brak opracowań z zakresu historii polskiego języka społeczno-politycznego oznacza, że nasza wiedza o kluczowych procesach dokonujących się od końca XVIII wieku jest - mimo ogromu literatury - powierzchowna.

Odwołam się do C.S. Lewisa, który jest nie tylko autorem Opowieści z. Narnii, ale też fascynujących studiów z dziejów kultury średniowiecza i renesansu oraz doskonałego szkicu o semantyce historycznej pod tytułem Studies in Words. Lewis pisze w nim o niebezpiecznym znaczeniu (dangerous sense) badanych słów, czyli takim, które narzuca się automatycznie, jest niezwykle sugestywne, ale może być i często jest błędne (Lewis 1996: 12). Lewis twierdził wręcz, że dla Anglika drugiej połowy XX wieku lektura wielkich klasyków realistycznej powieści XIX-wiecznej, na przykład Waltera Scotta, Jane Austen czy Charlesa Dickensa, może być trudniejsza niż

1946 roku „Annales. Économies, Sociétés, Civilisations”, od 1994 roku „Annales. Histoire, Sciences sociales”). Jedna z najważniejszych szkół w światowej historiografii, kładąca nacisk na metody i dorobek nauk społecznych w badaniu procesów historycznych. Za jej twórców i przedstawicieli tzw. pierwszego pokolenia uważa się Marka Blocha (1886-1944) i Luciena Febvre’a (1878-1956). Postulowali oni reformę badań historycznych i sformułowali program historii totalnej, łączącej w sobie historię gospodarczą i społeczną, antropologię historyczną, historię mentalności i geografię historyczna, zrywającej z dominacją historii politycznej [przyp. red.]. 
lektura Chaucera czy innych autorów średniowiecznych. Kiedy niespecjalista czyta Chaucera, nie ma wątpliwości, że obcuje z tekstem trudno zrozumiałym, sięga więc do słownika i zastanawia się nad znaczeniem słów. Gdy czytamy Austen i Dickensa, zdaje się nam, że mamy do czynienia z angielszczyzną niemal współczesną, bez trudu zrozumiała. To poczucie jest złudne i sprawia, że nie zauważamy subtelnych przesunięć znaczeń w słowach i frazach wydawałoby się doskonale nam znanych, przez co mylnie odczytujemy treść czytanych dzieł. Lewis nie zajmuje się znaczeniem pojęć społeczno-politycznych, lecz fraz i słów z życia codziennego. Podkreśla między innymi, jak różne znaczenia mogą się kryć w zwrocie tak banalnym i powszechnie znanym jak I dare say. Jego przestrogi stosują się jednak jak najbardziej do polskiego języka społeczno-politycznego sprzed dwóch stuleci. I w tym przypadku, czytając źródła, musimy zadawać sobie pytanie, czy słów zdawałoby się oczywistych nie można by lub wręcz należałoby spróbować zrozumieć inaczej.

\section{KK: Czy może Pan podać jakiś prryktad?}

MJ: Przyjrzyjmy się reakcjom polskich elit na upadek Rzeczypospolitej pod koniec XVIII wieku. Sto lat temu ukazał się esej Ignacego Chrzanowskiego Caym byt Wirgiliusz dla Polakón po utracie niepodlegtości (Chrzanowski [1915] 1972: 229-249). Jest to analiza Wergiliańskich odwołań w polskiej literaturze pierwszych kilkunastu lat po trzecim rozbiorze. Chrzanowski pokazuje, że dzięki Trenom Kochanowskiego polska kultura dysponowała wspaniałym wzorcem wyrażania bólu w obliczu osobistej tragedii; nie dysponowała natomiast językiem, który mógłby wyrazić tragedię dotykająca całego społeczeństwa. Języka służącego wyrażaniu klęski narodowej dostarczyła Polakom dopiero romantyczna poezja z Mickiewiczem na czele. Mowa zatem o okresie po klęsce powstania listopadowego. Wtedy to powstał język, którym aż do 1989 roku Polacy mówili i myśleli o tragediach narodowych.

Jeśli zatem pod koniec XVIII wieku polska kultura nie dysponowała językiem służącym do opisu tragedii narodowej, to czym dysponowała? Chrzanowski pokazuje, że to Wergiliusz dał Polakom przełomu wieków XVIII i XIX formy wyrazu uczuć, oczekiwań i ideałów, kategorie służące rozumieniu świata. Mowa przede wszystkim o często przez Wergiliusza wyrażanej nadziei na to, że z upadłej Troi powstanie Rzym, że zrodzi się nostris ex ossibus ultor. Nawet jeśli wywód Chrzanowskiego wymaga uzupełnienia o dwa dodatkowe klucze interpretacyjne, to jest tradycję stoic- 
ką („,cnota” indywidualna jako jedyna kotwica wśród zmiennych obrotów Fortuny) i Biblię (nadzieja mesjańska), to jego podstawowa teza się broni: zanim powstał własny styl mówienia o narodowym nieszczęściu, kultura polska posługiwała się wzorcami z wcześniejszej tradycji. Była to konieczna reakcja na brak środków wyrazu, brak pojęć umożliwiających konceptualizację nowego i nieznanego stanu rzeczy.

Jak pokazuje Marek Nalepa, język klasycystycznej estetyki nie pozwalał w pełni wyrazić ogromu zbiorowego nieszczęścia (Nalepa 2002: 99 i n.). Z tym tylko że wywód Nalepy opiera się na błędnym, moim zdaniem, założeniu. Nalepa zakłada, że polskie elity oświeceniowe głęboko i boleśnie odczuwały upadek Polski, lecz nie dysponowały językiem służącym jego wyrażaniu. W tym założeniu zawarta jest sugestia, że człowiek najpierw odczuwa nieszczęście, a potem je wyraża - albo nie wyraża - w języku. O ile założenie to może się odnosić do indywidualnych klęsk i niepowodzeń, o tyle nie odpowiada, moim zdaniem, sytuacji zbiorowości. Klęskę zbiorową odczuwamy o tyle tylko, o ile możemy ją wyrazić. Zmodyfikowałbym zatem tezę Nalepy: język polskiego życia społecznego nie potrafił wyrazić klęski trzeciego rozbioru - i dlatego utrudniał jej zauważenie i zrozumienie. Zauważyć cokolwiek możemy bowiem tylko wtedy, gdy uprzednio dysponujemy kategoriami opisu. Innymi słowy, nie ma percepcji poza kategoriami.

KK: Czy to oznacza, że nasze potoczne wyobrażenia o rozpaczy polskich elit po upadku Rzeczypospolitej maja niewiele wspólnego zówcresna ržeczywistościa?

MJ: Po trzecim rozbiorze w polskim piśmiennictwie często pojawiają się frazy typu „nie jesteśmy już narodem”. Są one z reguły interpretowane jako wyraz rozpaczy. Jeżeli uznamy jednak, że naród był rozumiany jako całość polityczna, to stwierdzenie „nie jesteśmy już narodem” znaczy po prostu stwierdzenie oczywistego faktu, że mianowicie ciało polityczne, jakim była Polska, przestało istnieć. Pod koniec XVIII wieku nie funkcjonowało jeszcze romantyczne rozumienie narodu.

W polemice z fraza , nie jesteśmy już narodem” Wybicki pisze , jeszcze Polska nie umarła, kiedy my żyjemy". To zdanie ma wymiar rewolucyjny. Oznacza bowiem, że trwanie narodu jest możliwe w zbiorowej świadomości, to znaczy poza instytucja polityczną. Ale to silne - mówiąc w uproszczeniu - przed Wybickim spojenie narodu z instytucją polityczną możemy w pełni zrozumieć jedynie dzięki poważnej analizie historii pojęcia „naród” (por. Janowski 2009, Żbikowski 1998). Jego ewolucja dawałaby też 
szansę na lepsze zrozumienie ciagle słabo rozpoznanego problemu lojalności politycznej polskiej szlachty po rozbiorach (por. Czubaty 2005, Kizwalter 1999, Mycielski 2004, Walicki 2000). Dominujący w historiografii obraz roku 1795 jako upadku „państwa”, utraty „suwerenności” i początku epoki walk o „niepodległość” czy też epoki „powstań” jest jednostronny dlatego, że „państwo”, „niepodległość” i „powstanie” (nie mówiąc już o „suwerenności”) nie nabrały jeszcze swojego późniejszego znaczenia. Obraz ten trzeba może nie tyle odrzucić, ile go zniuansować, tak aby uwzględniał rozmaite przemiany polityczne, których kulminacją był upadek Rzeczypospolitej.

KK: Okres transformacji niemieckiego jezyka społeczno-politycznego w drugiej potowie XVIII i pierwszej potowie wieku XIX Koselleck okereślit mianem „crasu siodta”, czyli „usadawiania się" nowoczesnych znaczeń kluczowych pojéc (zob. Ortowski 2001: 19, 24-25). Czy w polskim jezyku spoteczno-politycznym dokonywaty sie wówczas równie głębokie przemiany?

MJ: Zdecydowanie tak. Przyjrzyjmy się bliżej czasom stanisławowskim. Można w tym okresie dostrzec dwie lub nawet trzy warstwy semantyczne języka społeczno-politycznego. Ta, która sprawia wrażenie najbardziej archaicznej, odwołuje się do instytucji, ideałów i wyobrażeń nietkniętych jeszcze ujednolicającym pokostem prawa rzymskiego, renesansowymi i humanistycznymi ideami państwa, suwerenności czy racji stanu. Nie odróżnia się w niej między władzą a własnością, między stanem szlacheckim a państwem. Niesłychanie trudno jest opisać tę warstwę języka, ponieważ trzeba to robić za pomoca pojęć, które powstały później, co jedynie mnoży nieporozumienia. Na tę archaiczną warstwę nakłada się druga, o renesansowej proweniencji, opisująca Rzeczpospolita w kategoriach antycznego Rzymu, przefiltrowanego przez renesans. Można ją określić jako warstwę myślenia „republikańskiego”, myślenia, za którego patronów uznać można Machiavellego, a może także Tacyta i Liwiusza, odczytywanych na sposób renesansowy. Wreszcie na te dwie warstwy nakłada się trzecia, zdecydowanie nowoczesna, która nadaje pojęciom znaczenie „oświeceniowe” - czyli z grubsza biorąc takie, które skłonni bylibyśmy uznać dziś za naturalne i oczywiste.

Te warstwy semantyczne odzwierciedlają rzeczywistość ustrojową. Polska połowy XVIII wieku to przedziwne ciało polityczne, składające się z mnóstwa małych komityw. To wielopiętrowa struktura korporacyjna ze zdecentralizowaną suwerennością. Język pojęciowy w swej „archaicz- 
nej" warstwie oddaje charakter tego systemu politycznego. Można w nim jednak wychwycić także „republikańską” warstwę znaczeniową o renesansowo-antycznej proweniencji. W czasach Stanisława Augusta na to amorficzne ciało polityczne nakłada się „czapa” - a właściwie maleńka czapeczka - nowoczesnych struktur państwowych. Tym samym w publicystyce oświecenia zaczyna się dokonywać przemiana siatki pojęć politycznych: ich znaczenia zaczynają się klarować, ujednolicać, racjonalizować.

Trzeci rozbiór Polski dokonuje się zatem w momencie, gdy niejasne, „przedoświeceniowe” pojęcia nie są w stanie „ując ć mentalnie tej nowej sytuacji. Skumulowały się bowiem wówczas dwa zjawiska: Rzeczpospolita upadła w momencie, kiedy przekształcała się z owej amorficznej, wczesnonowożytnej politei w nowoczesne (w XIX-wiecznym sensie tego słowa), scentralizowane państwo biurokratyczne. Proces ten był dopiero w zalążku, ale z dzisiejszej perspektywy trudno go nie zauważyć. Wskutek zaborów doznał on ogromnego przyspieszenia, z tym tylko, że owo nowoczesne państwo było państwem zaborczym. Te dwa procesy - tworzenia się nowoczesnego państwa i wejście państw zaborczych na miejsce Rzeczypospolitej-logicznie całkowicie niezależne, splatały się w oczach współczesnych w całość, jeszcze bardziej utrudniając im zrozumienie sytuacji.

W efekcie dawne znaczenia dźwięczą wciąż jeszcze w tle nowych. „Naród” jest ciągle jeszcze narodem uprzywilejowanych. W słowie „Rzeczpospolita" ciagle pobrzmiewa znaczenie Personenverband, korporacji raczej niż formy państwa. „Państwo”, ciągle może znaczyć „włość”, „klucz” czy ogólnie „panowanie”. „Ojczyzna” migoce znaczeniami od zupełnie nowoczesnej ojczyzny Polaków przez ojczyznę lokalną aż do ojczyzny - ojcowizny. „Niepodległość” wciąż jeszcze jest najszerzej pojętą niezależnością od najróżniejszych rzeczy, a nie tylko suwerennością państwową. „Obywatel” może znaczyć mieszkańca, a może - uprzywilejowanego. „Powstanie” to ciagle także „pospolite ruszenie”. A „wolność” to wciąż jeszcze również (nie jedynie) przywilej, a rewolucja - obrót Koła Fortuny.

KK: Prayjrzyjmy sie tym procesom, na prayktad w odniesieniu do pojecia ojczyzny.

MJ: W XVIII wieku w pełnej sile pozostawał stary termin prawniczy, używany w testamentach i sprawach o dziedziczenie ziemi. Ojczyzna była wówczas ojcowizną - ziemią pozostała po ojcu. Ojczyzna to zarazem „Patria", ale także wszystko, co może istnieć między nimi, a co obecnie określa się jako „ojczyznę lokalną”. Mam wrażenie, że przejęty z łaciny termin polityczny trafił w polszczyźnie na starsze, lokalne znaczenie i pod jego wpły- 
wem uległ „decentralizacji”, utracił precyzję i zaczął oznaczać rozmaite koncentryczne kręgi lojalności, od małej - prywatnej, przez polityczna, ale - używając anachronicznej terminologii - poniżej szczebla państwowego, taka jak ziemia albo Korona bądź Litwa, przez całą Rzeczpospolita Obojga Narodów, aż do poziomu jeszcze szerszego - do Ojczyzny niebieskiej, miejsca, do którego zdąża każdy chrześcijanin. Jak podpowiedział mi Marek Gensler z Uniwersytetu Lódzkiego, to współistnienie w słowie „ojczyzna" koncentrycznych kręgów słychać w znanej nam doskonale zwrotce kolędy Bóg się rodæi. Po słowach „Błogosław Ojczyznę miłą” następuje wyliczenie jej znaczeń, czyli po pierwsze, „dom nasz”, po drugie, „majętność całą, i po trzecie, „Twoje [w późniejszych wersjach „wszystkie”] wioski z miastami”.

KK: Koselleck pokazat, że na przetomie XVIII i XIX wieku w niemieckim obszarze jezykowym dokonata sie ,syngularyzacja” pojeć. Jako przyktad podaje przejscie od frazy „Königlich-Preußische Staaten” (Państwa Królewsko-Pruskie) do oficjalnego użycia stowa „Staat”" (państwo) w ličbbie pojedynczej (Koselleck. 2001). Czy podobny proces dokonat sie wówczas w polszczyźnie w odniesieniu do stowa "panstwo"?

MJ: Tak. W XVIII wieku i w języku, i w rzeczywistości społecznej niejednoznaczna była relacja między słowami „państwo” i „prowincje”, co wynikało z braku klarownych wyznaczników suwerenności państwowej. Zresztą zanim „państwa Rzeczypospolitej” zaczęły ustępować miejsca idei Rzeczypospolitej jako jednolitego państwa, wydawało się, że słowo „państwo" zostanie zdetronizowane przez „stan”. Termin ten istnieje w europejskim życiu politycznym od dawna i oznacza grupę społeczną rządząca się odrębnymi prawami. Jego łaciński (status), francuski (état) i włoski (stato) odpowiednik łączyły w sobie dzisiejsze znaczenia „państwa” i „stanu”. Bliskość słów oznaczających oba te pojęcia jest również bardzo widoczna $\mathrm{w}$ języku angielskim (state i estate) i niemieckim (Staat i Stand). W polskim języku politycznym wielokrotnie używano łacińskich fraz typu ratio status czy arcana status, które musiały oswajać uczestników polskiego życia politycznego z możliwością użycia słowa „stan” nie tylko dla określenia grupy społecznej, ale też jednostki politycznej. Brak klarowności semantycznej odzwierciedla rzeczywistość pozajęzykową. Organizacja polityczna typu „państwo" nie była wówczas czymś w sposób oczywisty odmiennym od organizacji politycznej typu „stan”. Teoretycy polityczni czasów stanisławowskich potrafili co prawda przedstawić bardzo nowoczesną teorię 
państwa wolnych i równych obywateli. Ale w ich wywodach pobrzmiewało jeszcze echo personalnej koncepcji państwa. Nawet u najbardziej postępowych myślicieli ciągle dawały się zauważyć odwołania do kategorii stanowych. Jeszcze w czasach Księstwa Warszawskiego Józef Kalasanty Szaniawski używał neologizmu „krajostan”, który nie oznaczał, jak moglibyśmy się dziś domyślać, „stanu kraju”, ale był z grubsza synonimem państwa.

KK: Tym, co czyni przypadek Polski szczególnie interesujacym, jest fakt, że nowoczesny polski jezyk spoteczno-polityczny ksztaltowat sie pod zaborami, w spoteczeństwie pozbawionym wlasnego państwa.

MJ: Brak państwowości był częściowo rekompensowany odniesieniami historycznymi z jednej i etnograficznymi z drugiej strony. Dopiero po 1831 roku, gdy w kulturze polskiej zatryumfował romantyzm, w zmienionych warunkach ideowych i politycznych wykształcił się język polskiego patriotyzmu, aktualny przez następnych sto kilkadziesiąt lat. Ciagle jednak nie wiemy, w jaki sposób brak państwowości i tym samym podzielona sfera publiczna oraz historyczno-etnograficzne kompensacje wpłynęły na kształtowanie się polskich pojęć podstawowych. W efekcie nie wiemy, w jakiej kondycji znajdował się polski język społeczno-polityczny po stu latach funkcjonowania w trzech zaborach. Nie wiemy, jak w 1918 roku Polacy z Poznania, Warszawy i Krakowa rozumieli pojęcia „naród” i „państwo”. Być może jednak większe znaczenie niż różnice terytorialne miały różnice ideologiczne i pokoleniowe. Tego też nie wiemy. Przed nami ogrom badań.

KK: Takize dostownie. W Instytucie Historycznym Polskiej Akademii Nauk zespót pod Pana kierownictwem rozpoczyna wtaśnie prace nad badaniem polskiego jezyka spoteczno-politycznego w XVIII, XIX i XX wieku. Jest to pierwsza w Polsce zespołowa próba zmierzenia sie z. tym zadaniem ${ }^{2}$. Lista baset powstaje i pewnie bẹdzie dtuga. Gdyby miat Pan jednak wskazać kilka pojeć, bez których dogtebnej znajomości nie jesteśmy w stanie zrozumiećcolskiej historii w ostatnich trzech stuleciach, jakie hasła wymienitby Pan w pierwszej kolejności?

MJ: Myślę, że na tej liście kluczowych pojęć powinny znaleźć się oprócz przywoływanych już wyżej narodu, ojczyzny, państwa i Rzeczypospolitej,

${ }^{2}$ Mowa o finansowanym od kilku miesięcy przez Narodowe Centrum Nauki (OPUS 10) projekcie „Historia pojęć społeczno-politycznych w Polsce XVIII-XX wieku” [przyp. red.]. 
także: dom, niepodległość, obywatel, powstanie, rewolucja, wolność i zdrada. Dysponujemy co prawda opracowaniami szczegółowymi na temat poszczególnych okresów lub kontekstów posługiwania się niektórymi z tych terminów, ale ciagle brakuje syntez sytuujących przemiany języka na tle przemian społeczno-politycznych w dłuższej perspektywie czasowej. Mnie osobiście najbardziej interesują kwestie związane z rozumieniem pojęcia narodu.

KK: Cұy może Pan żdradzৃic, jak realizacja kierowanego przęz Pana projektu bedzie wygladata w praktyce?

MJ: Chętnie bym zdradził, gdybym tylko wiedział... Początkowa część realizacji grantu ma na celu uszczegółowienie metod i sposobów działania na podstawie zapoznania się z dorobkiem historiografii, w których badania nad semantyką historyczną są bardziej zaawansowane. We wrześniu rozpoczęliśmy w Zakładzie Historii Idei i Dziejów Inteligencji comiesięczne seminarium metodologiczne. Pojawiają się na nim coraz to nowe pytania o stosunek historii pojęć do historii idei, historii słów czy historii mentalności. Dyskutujemy też koncepcję Michaela Freedena, który łączy historię pojęć z badaniem ideologii, rozumianych jako swoiste systemy pojęć (Freeden 1996, 2003). To wszystko domaga się przemyślenia i mam nadzieję, że nasza praktyka wyłoni się w konfrontacji z różnymi tradycjami badawczymi.

Analizowanie semantyki historycznej to przedzieranie się przez gąszcz tekstów. Wymaga ono nie tylko dużej wiedzy, ale też olbrzymiej uważności. Szczególnie wobec tych wypowiedzi, w których coś „zgrzyta”, w których znaczenia słów nie są dla nas oczywiste. Najpierw konieczne jest jednak określenie korpusu źródeł, które będziemy analizować. Zakładam, że dzięki zbiorowemu sczytywaniu tych samych tekstów uda nam się uniknąć ryzyka przypadkowości i zarzutu niereprezentatywności cytatów, które posłużą nam jako ilustracje głównych procesów dokonujących się w polskiej semantyce historycznej na przestrzeni trzech ostatnich stuleci.

KK: Wtasnie te zarzuty stawiano Koselleckowi i jego „Geschichtliche Grundbegriffe”. Inni z kolei krytykowali Kosellecka za ,wedrowanie po szcrytach" (niem. Gipfelwanderung), czyli ograniczenie przedmiotu badan do jezylka niemieckich

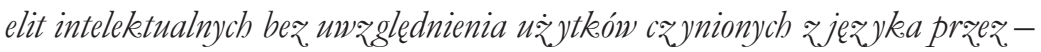
by pozostać w metaforze - mieszkeancón dolin, czyli traw. zwyklych ludzi. Jak. 
zamierza Pan, piszac historie polskiego jezyka społeczno-politycznego, uniknać tego niebezpieczenstwa?

MJ: Zanim odpowiem na Pani pytanie, chciałbym wyjaśnić, że ,wędrowanie po szczytach" miało pierwotnie inne znaczenie niż to, które nadali mu później krytycy. Najbardziej chyba znane użycie tej frazy, w nieco innej formie: „wędrówka grzbietem górskim”, znajdujemy w przedmowie do jednego z najbardziej klasycznych dzieł historii idei, jakim jest Powstanie historyzmu Friedricha Meineckego ${ }^{3}$. „Można byłoby - pisał Meinecke przedstawić genezę i rozwój idei historyzmu na przykładzie myślicieli mało istotnych, lecz zasługujących na uwagę. Jeśli jednak chcemy połączyć ze sobą przedstawienie ogólnego przebiegu wydarzeń z konkretną specyfiką rozwoju historyzmu, to pozostaje nam tylko podjęcie swego rodzaju wędrówki grzbietem górskim (Gratwanderung) i zmierzanie od jednego z wysokich szczytów ku następnemu, przy czym możliwe są także spojrzenia na boki, ku niezdobytym bocznym szczytom i dolinom" (Meinecke 1947: 6). Wędrówka grzbietem, czy granią, nie oznacza tu lekceważenia niższych partii gór, lecz jest punktem obserwacyjnym, z którego owe niższe okolice najlepiej widać. Wydaje mi się zresztą, że ten konkretnie zarzut wobec Kosellecka jest w oczywisty sposób nietrafiony. Koselleck nie ograniczał się przecież do badania koryfeuszy myśli politycznej: badał słowniki i encyklopedie, odezwy polityczne i teksty prawnicze. Pod tym właśnie względem badanie historii pojęć przez Kosellecka różni się od historii idei tak jak była ona uprawiana przez na przykład Meineckego.

Istnieją natomiast poważniejsze $i$, jak mi się zdaje, wymagające więcej namysłu zarzuty wobec programu badawczego Kosellecka. Wychodząca z zupełnie odmiennych założeń teoretycznych szkoła Cambridge z Johnem Pocockiem i Quentinem Skinnerem na czele analizuje konkretne konteksty, w których dane pojęcia były używane. Skinner daje bardzo zabawny przykład, jak kontekst określa znaczenie wypowiedzi: „The manager feels you may wish to know you are now overdrawn on your current account” (Skinner 1970, cyt. za: King 1983: 263, por. także Waśkiewicz 1998) ${ }^{4}$. Konwencje, czyli zjawisko tyleż językowe, co kulturowe, określają znaczenie tej wypowiedzi, która, formalnie rzec biorąc, jest informacja, ma jednak oczywisty charakter ostrzeżenia. Takich niuansów badanie historii poszczególnych pojęć mogłoby nie wychwycić. Można zatem zarzucać Ko-

\footnotetext{
${ }^{3}$ Friedrich Meinecke (1862-1954), niemiecki historyk, uznawany za twórcę terminu „historia idei”; po 1945 roku pierwszy rektor założonego przez aliantów w Berlinie Zachodnim Wolnego Uniwersytetu [przyp. red.].

${ }^{4}$ Dziękuję bardzo Piotrowi Kuligowskiemu za udostępnienie mi jego niepublikowanego referatu, porównującego szkołę z Cambridge z niemiecką Begriffsgeschichte [M.J.].
} 
selleckowi, że jego historia pojęć, obejmująca dłuższe okresy historyczne, w sposób sztuczny łączy ze sobą różne zjawiska, miesza konteksty, które buduja znaczenia pojęć. Koselleckowi zarzucano też, że odwołuje się do dawnych słowników i encyklopedii, które nie podają kontekstu użycia pojęć, nie mówiąc już o tym, że często „konserwują” znaczenia, podając takie, które zdążyły wyjść z użycia.

Te zarzuty są oczywiście poważne, ale w gruncie rzeczy każdemu badaniu czegokolwiek w dłuższej perspektywie czasowej można postawić zarzut, że przedmiot badania podlega zmianie w ciagu badanego okresu. Nie jest to jednak powód, aby nie prowadzić badań w perspektywie longue durée. Co więcej, właśnie pokazanie przemian znaczenia pojęć w dłuższym okresie czasu najlepiej ukazuje przemiany kontekstów.

Wracając jednak do Pani pytania o ograniczenie badań do elit - nie sądzę, by groziło nam to ryzyko. Z jednej strony bowiem nie należy odrzucać podejścia Meineckego: nasze „wędrowanie po szczytach” pozwoli lepiej widzieć to, co działo się wówczas w dolinach. Inaczej rzecz ujmując: język pojęciowy kształtuje się w dużym stopniu „na szczytach”, bo inteligencja (które to pojęcie jest również pojęciem historycznie zmiennym, ale pomińmy to) jest warstwą profesjonalnie zajmująca się słowami i to ona dostarcza pojęć, używanych później przez inne grupy społeczne.

Z drugiej zaś strony, także i dla tych innych grup nie brakuje nam źródeł, choć oczywiście jest ich o wiele mniej niż dla warstw (czy też grup lub klas) wyższych. Wbrew wyrażanemu czasem przekonaniu o tym, że nie mamy historii polskich chłopów, istnieje dość dużo tekstów dających wgląd $w$ ich zbiorową mentalność czy też to, co E.P. Thompson określił swego czasu mianem ekonomii moralnej (moral economy) (Thompson 1971). Mamy na przykład akta Referendarii Koronnej z XVIII wieku, czyli sądu, który orzekał w sprawach chłopów z dóbr królewskich (Keckowa, Błoński 1955-1957). Chłopi ci mieli prawo wnieść do Sądu Królewskiego oskarżenie przeciwko dzierżawcy dóbr. Można wręcz powiedzieć, że istniała pewna wspólnota interesów między chłopami i królem przeciwko dzierżawcy: podczas gdy temu ostatniemu zależało na uzyskaniu maksymalnego zysku, królowi zależało na tym, aby jego dobra nie zostały zniszczone w ciagu jednego pokolenia, lecz mogły przynosić trwały dochód, co z kolei oznaczało sprzeciw wobec wyzysku chłopów. Dlatego też chłopi protestujący w Warszawie przeciwko uciskowi ze strony dzierżawcy mogli liczyć na to, że sąd uzna ich racje. Podobnym rodzajem źródeł są wiejskie księgi sądowe. Polecam świetną książkę przedwojennego historyka prawa Józefa Rafacza o ustroju autonomicznej wsi w Małopolsce XVIII wieku (Rafacz 1922). 
Mamy też kapitalne, oparte na szerokiej bazie źródłowej prace o historii robotników w czasach tworzenia się kapitalizmu - od Niny Assorodobraj po Walentynę Najdus i Annę Żarnowską (Najdus 1983, Assorodobraj 1946, Żarnowska 1974). Warto też wspomnieć o najnowszej pracy Wiktora Marca o „plebejskim doświadczeniu politycznym” podczas rewolucji 1905 roku (Marzec 2016). Innymi słowy, choć mogłoby się wydawać, że masy ludowe są nieme, dysponujemy źródłami i opracowaniami, które dają wgląd w ich stan świadomości.

KK: Kiedy możemy sie spodziewać pierws zych efektów realizacji Pana projektu? MJ: Może lepiej porozmawiajmy o czymś innym...

KK: Cayli: ciag dalszy nastapi. Driekuje za rozmowe.

Bibliografia:

/// Assorodobraj N. 1946. Poczatki klasy robotniczej. Problem rake roboczych w przemyśle polskim epoki stanisławowskiej, przedm. J. Chałasiński, Czytelnik.

/// Brunner O., Conze W., Koselleck R., red. 1972-1997. Gescbicbtliche Grundbegriffe, Klett-Cotta.

/// Chrzanowski I. 1971 [1915]. Czym byt Wirgiliusz dla Polakón po utracie niepodlegtości, [w:] tegoż, Optymizm i pesymizm polski. Studia z historii kultury, wybór A. Biernacki, Państwowe Wydawnictwo Naukowe, s. 229-249.

/// Czubaty J. 2005. Zasada „dwóch sumieñ”. Normy postepowania i granice kompromisu politycznego Polaków w sytuacjach wyboru (1795-1815), Neriton.

/// Freeden M. 1996. Ideologies and Political Theory. A Conceptual Approach, Clarendon Press.

/// Freeden M. 2003. Ideology. A Very Short Introduction, Oxford University Press.

/// Janowski M. 2009. Rozpacz. oświeconych? Przemiana polskiego jezylka politycznego a reakcje na upadek Rzeczypospolitej, „Wiek Oświecenia”, t. 25, s. 29-60.

/// Keckowa A., Błoński A., red. 1955-1957. Ksiegi Referendarii Koronnej z drugiej połowy XVIII wieku, t. 1-2, Książka i Wiedza. 
/// King P., red. 1983. The History of Ideas, red. P. King, Barnes \& Noble Books.

/// Kizwalter T. 1999. O nowoczesności narodu. Przypadek polski, Semper.

/// Koselleck R. 2001. Historia pojéc a historia spotecæna, [w:] tegoż, Semantyka bistorycæna, tłum. W. Kunicki, Wydawnictwo Poznańskie.

/// Lewis C.S. 1996 [1960]. Studies in Words, Cambridge University Press, 2. wyd.

/// Marzec W. 2016. Rebelia i reakcja. Rewolucja 1905 roku i plebejskie dośniadczenie polityczne, Wydawnictwo Uniwersytetu Lódzkiego - Universitas.

/// Meinecke F. 1947 [1936]. Die Entstehung des Historismus, wyd. 2, Oldenbourg.

/// Mycielski M. 2004. „Miasto ma mies₹̨anców, wieś obywateli”. Kajetana Koźmiana koncepcje wspólnoty politycznej (do 1830 roku), Wydawnictwo Uniwersytetu Wrocławskiego.

/// Najdus W. 1983. Polska Partia Socjalno-Demokratyczna Galicji i Ślaska 1890-1919, Państwowe Wydawnictwo Naukowe.

/// Nalepa M. 2002. Takie życie džiś nasze, gdy Polska ustaje... Pisarze stanisławowscy a upadek Rzecrypospolitej, Fundacja na Rzecz Nauki Polskiej.

/// Orłowski H. 2001. Reinhart Koselleck - szkoła bielefeldrka - semantyka bistoryczna, [w:] R. Koselleck, Semantyka bistoryczna, tłum. W. Kunicki, Wydawnictwo Poznańskie, s. 7-27.

/// Pepłowski F. 1961. Stownictwo i frazeologia polskiej publicystyki okresu Oświecenia $i$ Romantyzmu, Państwowy Instytut Wydawniczy.

/// Rafacz J. 1922. Ustrój wsi samorz̨qdnej matopolskiej w XVIII wieku, nakładem Uniwersytetu Lubelskiego.

/// Skinner Q. 1970. Convention and the Understanding of Speech Acts, „Philosophical Quarterly", nr 79, s. 118-138.

/// Thompson E.P. 1971. The Moral Economy of the English Crowd in the Eighteenth Century, „Past \& Present”, t. 50, nr 1, s. 76-136.

/// Walicki A. 2000. Idea narodu w polskiej myśli ośnieceniowej, IFiS PAN.

/// Waśkiewicz A. 1998. Interpretacja teorii politycznej. Spór o metode we wspótczesnej literaturze anglosaskiej, Wydawnictwo Naukowe Scholar. 
/// Żarnowska A. 1974. Klasa robotnicza Królestwa Polskiego (1870-1914), Państwowe Wydawnictwo Naukowe.

/// Żbikowski P. 1998. ... bolem śmiertelnym ściśnione mam serce... Rozpacz oświeconych u śródet prąełomu w poezji polskiej w latach 1793-1805, Leopoldinum. 